\title{
Outro mundo é possível. Como reinventar a crítica?
}

\author{
Another world is possible. How to reinvent critique?
}

Otro mundo es posible. ¿Cómo reinventar la crítica?

\begin{abstract}
ENTRE CONTROVÉRSIA E HEGEMONIA: OS TRANSGÊNICOS NA ARGENTINA E NO BRASIL. Motta R. Rio de Janeiro: Editora Fiocruz; 2018. 260 p. ISBN 978-85-7541-618-1.
\end{abstract}

doi: 10.1590/0102-311X00169319

O debate em torno dos organismos geneticamente modificados (OGMs) é, a despeito do que muitos tentam defender, um "tema quente". Precursoras, as técnicas de cruzamento nos Estados Unidos, na década de 1940, provocavam muitas polêmicas em torno da formação e da cura de uma patologia vegetal conhecida por galha da coroa. Desde os anos 1980, as plantas geneticamente modificadas, inventadas em laboratórios na Bélgica, dividem opiniões sobre os problemas globais ambientais e alimentares. Hoje, na China, o mundo pós-transgênico conheceu, estupefato, a clonagem de primatas por meio de edições genômicas e transferência nuclear de células somáticas (técnicas referenciadas, respectivamente, por CRISPR e TNCS).

Cruzamento, transgenia e edição genômica contam, em suas particularidades, a história moderna da biotecnologia. No entanto, essa seria uma maneira muito pobre de narrar os eventos. Seria conferir-lhes uma ideia implícita de progresso. Seria pior, pois incorreria naquilo que Chimamanda Ngozi Adichie chama de "o perigo da história única” 1 . Evitar esse perigo foi um dos cuidados que envolveu a escrita do livro Entre
Controvérsia e Hegemonia: os Transgênicos na Argentina e no Brasil.

Fruto da tese de doutorado da autora, os sete capítulos que agora se apresentam, para além de exporem um vasto panorama da história dos transgênicos no Brasil e na Argentina (19902014), fazem eclodir outras dimensões sobre o tema, conferindo-lhe outra versão. Das lutas de contestação dos movimentos sociais (rurais e urbanos), passando pelas cadeias internacionais de commodities, até a geopolítica do capitalismo, o que está em jogo é "a procura de explicações para a construção dos OGMs como um problema político” (p. 50) que exceda o domínio do gene.

O capítulo 1 desenha o problema. É costurado a partir de cinco grandes abordagens: da economia e da ecologia política da alimentação, dos estudos sociais em ciência e tecnologia, dos estudos em democracia e políticas públicas e, por fim, dos estudos sobre movimentos sociais. Faz-se um extenso levantamento de dados sobre as questões que circunscreveram a chegada dos transgênicos na América Latina a partir do ponto de vista comparativo dos grupos de contestação locais. Trata-se do modelo: sistemas similares apresentam resultados distintos.

Por essas razões, os capítulos 2 e 3 e os capítulos 4 e 5 trazem, respectivamente, a sequência cronológica dos eventos na Argentina e no Brasil. Elencam-se a rede de agentes envolvidos, os discursos mobilizados e as ações de contestação contra os transgênicos.

$\mathrm{Na}$ Argentina, a mensagem analítica resultante é a seguinte: as interpretações de agentes 
pontuais no micro (ONGs, campesinos, las mujeres de la plaza de mayo), sobre processos econômicos e políticos, e no macro (luta contra a passagem do modelo agrário para o desenvolvimento liberal exportador de commodities) fazem da luta anti-OGMs uma luta contra o neoimperialismo. Esse apelo, contudo, encontrou dificuldades de se alastrar pela população. Isso ocorreu porque é o setor primário agrário o que mais movimentou a economia daquele país ao longo de sua história recente. Ali, portanto, houve uma desmobilização social em face da bio-hegemonia de um sistema econômico e político historicamente estruturado.

No Brasil, a bio-hegemonia não se instalou, deixando aberta uma controvérsia pública sobre os transgênicos. Isso se deu por três motivos: falta de consenso científico, efervescência do ambientalismo e abertura democrático-institucional. Resulta daí um "dualismo na agricultura" (p. 118). Com efeito, esse dualismo encontrou visibilidade nas formações sociais e institucionais voltadas, de uma parte, ao agronegócio latifundiário exportador (Ministério da Agricultura, Pecuária e Abastecimento, bancada ruralista, sindicatos patronais) e, de outra parte, à agricultura familiar (Ministério do Desenvolvimento Agrário, Movimento dos Sem Terra, Articulação Nacional para Agroecologia). A dominação dos transgênicos na lavoura, aqui, se deu por meio de guerras públicas declaradas que dividiam o Estado e a população.

Esse panorama gera, logo adiante, um avanço e um entrave.

No capítulo 6, a análise comparativa é efetivamente empreendida. No caso argentino, a bio-hegemonia se construiu como resultado de uma série de alianças políticas das elites com o Estado, junto ao consentimento velado da população, sem difusão midiática. No caso brasileiro, as mobilizações forçaram legislações que impediam cultivos transgênicos. Além disso, órgãos estatais defenderam direitos humanos e conexões rurais e urbanas que acolheram outro modelo agrário. Essas e outras diferenças ganham um contorno explicativo potente em nível histórico-estrutural: "as bases dos movimentos sociais e a profissionalização das ONGs eram diferentes em cada país” (p. 189), e "a diferença reside no uso de estratégias que abriram o caminho para que os pontos de vista dos movimentos sociais alcançassem a esfera pública” (p. 192) de modo mais rápido e mais extenso no Brasil.
Essa interpretação se resume no conceito de “estruturas de oportunidades de ação”. A bio-hegemonia, preponderante na Argentina, ainda que contestada, representa a dificuldade de abertura dessas estruturas. A instauração da controvérsia pública, no Brasil, é a abertura destas, mesmo sem muito sucesso final.

A questão inicialmente formulada ensejou uma narrativa sobre "como a integração desse modelo agrário [de exportação de produtos de base] nas cadeias globais de commodities afeta as campanhas dos movimentos sociais contra os cultivos transgênicos" (p. 207). É o que faz a passagem ao capítulo 7.

Nas conclusões, a autora elenca cinco fatores que explicam a mobilização e a desmobilização social das contestações contra os transgênicos no Brasil e na Argentina: as condições de proteção contra a criminalização dos movimentos, a interdependência entre os três poderes, a pluralidade dos meios de comunicação, a proteção ao clientelismo e a estrutura das oportunidades políticas. Em maior ou menor grau, esses fatores fizeram com que, nas terras vizinhas, se instaurasse uma rede de alianças bio-hegemônica, ao passo que, no território nacional, a controvérsia pública resultou em uma guerra rural, com maiores perdas do que ganhos para os movimentos anti-OGMs. A ideia derradeira? "Para a mobilização social a tarefa principal é conectar as resistências territoriais e as lutas urbanas" (p. 232).

O resultado do livro é, com efeito, a abertura do acontecimento. Trata-se da exposição de outra história sobre os transgênicos, narrada desde o ponto de vista dos oprimidos 2 .

Ainda assim, como todo acontecimento, a instauração da genética como saber e práxis que reorientou a agricultura na América Latina é sempre ambígua. Ela guarda sua efetuação e sua contra-efetuação ${ }^{3}$. Sugiro que, para dar maior potência a essa narrativa no interior dessa ambiguidade, uma virada decolonial se faz imprescindível.

Brasil e Argentina são Estados modernos, filhos de um longo processo de colonização. O ponto de maior relevância do livro é, sem dúvida, manter acesa a memória das lutas sociais que sempre estiveram presentes nesses países, apesar de todos os fatores que permitiram seu "maior ou menor sucesso". E é precisamente essa a mudança de perspectiva decolonial na qual as ciências sociais devem se engajar, já que medir as re- 
lações sociais e sua história em termos de sucesso é muito perigoso.

No que concerne ao engajamento político, não é à toa que as reeleições no Brasil e na Argentina tiveram como estratégia, por parte dos próprios movimentos, difundir o medo da perda das suas poucas conquistas ao longo das últimas décadas. Nesse caso, o que é possível fazer/escrever após as últimas eleições nesses países, desde o ponto de vista da necessidade de reinvenção da crítica?

No que concerne à produção sociológica, com frequência, incorremos em tomar os "oprimidos" como derrotados. Todo esforço analítico que incorpore essa perspectiva flerta com a ideia de que as minorias não enxergaram a extensão da realidade, de que elas erraram a escala de atuação. Existe algo que excede a efetivação de uma mudança estrutural na agricultura e na alimentação e que se encontra, precisamente, naquilo que campesinos, indígenas, quilombolas, mulheres, dentre outros fazem para além dessa disputa: eles continuam existindo, reinventando seus modos de existência (contraefetuação) 4 . Assumir uma narrativa a partir desse ponto de vista não é mostrar como os grupos de contestação social minoritários enfrentam aquilo que os ameaça, mas, ao enfrentar aquilo que os ameaça, como eles reinventam outro mundo de possíveis.

Felipe Vargas 1

1 Universidade Federal da Bahia, Salvador, Brasil. fvargas85@gmail.com

\section{Informação adicional}

ORCID: Felipe Vargas (0000-0001-9194-8523).

1. Adichie C. The danger of a single story. TED, 2009. Video: 19:16 min. https://www.youtube. com/watch?v=D9Ihs241zeg (acessado em 29/ Ago/2019).

2. Cusicanqui SR. Oprimidos pero no vencidos: luchas del campesinato aymara y quéchua 1900-1980. 4a Ed. La Paz: La Mirada Selvaje; 2010.

3. Stengers I. L'invention des sciences modernes. Paris: Flammarion; 1994.

4. Cusicanqui SR. Princípio Potosí reverso. Madrid: Museo Nacional Centro de Arte Reina Sofia; 2010 . 